\title{
Detection of interleukin-22 secreting T-cells in piperacillin hypersensitive patients with cystic fibrosis
}

\author{
Andrew Sullivan ${ }^{1 *}$, Eryi Wang ${ }^{1}$, John Farrell ${ }^{1}$, Paul Whitaker ${ }^{2}$, Daniel Peckham², B Kevin Park', Dean Naisbitt ${ }^{1}$ \\ From 6th Drug Hypersensitivity Meeting (DHM 6) \\ Bern, Switzerland. 9-12 April 2014
}

Delayed-type cutaneous drug hypersensitivity is a T-cell mediated disease; the spectrum of conditions has been classified according to the phenotype and function of drug antigen-specific T-cells sub-sets. Importantly, this classification does not take into account tissue-specific cytokines such as interleukin-17 and interleukin-22. Both of these cytokines have been shown to play a role in numerous physiological and pathological processes. For example, elevated levels have been detected in patients with psoriasis and allergic contact dermatitis. To investigate this, we have focused on piperacillin, a $\beta$-lactam antibiotic used for the treatment of pulmonary exacerbations in patients with cystic fibrosis. Unfortunately hypersensitivity reactions (mean onset $=9.1$ days; symptoms include maculopapular rash, fever and/or flu-like symptoms) to this drug develop in $26-50 \%$ of treated patients. Piperacillin-specific T-cell clones were generated from 3 lymphocyte transformation test positive hypersensitive patients and 4 healthy donors, following priming of naïve $\mathrm{T}$-cells against piperacillin-exposed dendritic cells, to characterize T-cell phenotype (CD and chemokine receptor expression) and function (proliferation and secretion of cytokines/cytolytic molecules [IFN $\gamma$, 13, 17, 22 by ELIspot]). Seventy six CD4+ and CD8+ clones were isolated from the hypersensitive patients and shown to proliferate in the presence of piperacillin. Drug stimulation was associated with the secretion of IFN- $\gamma$ and IL13 from all clones. IL-22 secretion was detected from $64 \%$ and $75 \%$ of the CD4+ and CD8+ clones, respectively. In contrast, IL17 was not detected. Naïve T-cells cocultured with piperacillin and autologous dendritic cells showed concentration-dependent proliferation and

'University Of Liverpool, Centre for Drug Safety Science, UK

Full list of author information is available at the end of the article cytokine (IFN $\gamma$, IL13 and IL22) secretion. CD4+ and CD8 + clones generated from the primed T-cells also secreted IFN $\gamma$, IL13 and IL22 (CD4+ 50\%, CD8+ 67\%) following piperacillin stimulation. CCR1, CCR4 and CCR10 were expressed on all clones. Other chemokine receptors expressed on a limited number of clones included CXCR3, CXCR6, CCR2 and CCR9. In conclusion, these data show the involvement of IL22 secreting T-cells in the pathogenesis of piperacillin hypersensitivity reactions in patients with cystic fibrosis.

\section{Authors' details}

'University Of Liverpool, Centre for Drug Safety Science, UK. 'St James' Hospital, Regional Adult Cystic Fibrosis Unit, UK.

Published: 18 July 2014

doi:10.1186/2045-7022-4-S3-P108

Cite this article as: Sullivan et al:: Detection of interleukin-22 secreting

T-cells in piperacillin hypersensitive patients with cystic fibrosis. Clinical and Translational Allergy 2014 4(Suppl 3):P108.

Submit your next manuscript to BioMed Central and take full advantage of:

- Convenient online submission

- Thorough peer review

- No space constraints or color figure charges

- Immediate publication on acceptance

- Inclusion in PubMed, CAS, Scopus and Google Scholar

- Research which is freely available for redistribution

Submit your manuscript at www.biomedcentral.com/submit 